\title{
The Use of Dakonmatika Media Game As Efforts to Increase Mathematics Learning Results of the Fourth Grade Students at SD Negeri 61 Parepare
}

\author{
Sriyanti Mustafa ${ }^{1}$, Muhammad Siri Dangnga ${ }^{2}$, Fajar Bahari ${ }^{3}$ \\ Department of Mathematic Education \\ University of Muhammadiyah ParePare \\ ParePare, Indonesia \\ ${ }^{1}$ Sriyanti_mustafa@yahoo.co.id \\ ${ }^{2}$ Muhammad.siri@gmail.com \\ 33Fajarbahari271@yahoo.co.id
}

\begin{abstract}
The problem in this research was the low of mathematics learning result of students. The approach used in this research was quantitative and qualitative approach (mixed method) with the type of Classroom Action Research (CAR) which aims to know the improvement of mathematics learning result of learners by using dakonmatika game media. The subjects of this research were students of class IV of elementary school 61 Parepare of the year 2017/2018 as many as 22 students. Technique of data collection used was the provision of tests and observations. The instruments used were test result and observation sheets. The observation sheets consisted of students' activity and the teacher's ability to manage the lesson. Data analysis technique used was descriptive quantitative and qualitative. The results showed that the use of dakonmatika media can improve the fourth grade students' mathematics learning results at elementary school 61 Parepare, this was marked by the increasing of: (1) Average score of students' mathematics learning results in the first cycle of 71.06 increased to 82,73 in cycle II, (2) achievement of the students' learning completeness from cycle I was $64 \%$ increased to $95 \%$ in cycle II, or completely classical and (3) the increasing of students' activity average in learning process equal to $37,19 \%$ in cycle $I$ to $69.52 \%$ in cycle II.
\end{abstract}

Keywords—game media; dakonmatika; mathematics learning result

\section{INTRODUCTION}

Mathematics learning in elementary schools emphasizes understanding of the mathematics basic concepts and relationships between various number systems. [1] states in the mathematics learning of elementary, reinvention is expected. Reinvention finds an informal way of completing learning in the classroom. [1] also adds that elementary school students are still tied up with objects captured with the senses, so it is expected in abstract mathematics learning, students use more media as a tool.

To understand the use of media as a tool in mathematics learning, then conducted observations at SD Negeri 61
Parepare. The reason for the school selection wasthat the learning process of mathematics in the school was still limited in the use of media or props, the observation was done by observing mathematics learning process in the classroom and checking the average score of mathematics learning results in the school.

One of the materials studied in the math subjects of students in the fourth grade was the Largest Guild Factor (LGF) and the Smallest Partnership Multiplier (SPM). In the observation activity, the students learned that mathematics was a lesson that was difficult to understand and boring, so that the impact on the results of mathematics learning was low. It can be seen from the average of daily test result of students in math lesson which only reach 67, while Minimum Criterion of Completeness (MCC) which was set at school was 70 .

To overcome the above problems, teachers should be more creative and able to create an atmosphere of active and fun learning, not only fixated on the book package of learning as the main learning media. One of the media that can be used in mathematics learning especially on LGF and SPM materials was dakonmatika game media.

[2] states that dakon media is one of mathematics learning media consisting of half circle basin which amounted to 14 pieces. Two large half circle basins are located at the right and left edges. The rest are lined up between 2 large basins of 6 each. Besides [3] mentiones that dakonmatika is one kind of mathematics tool that can be used as media in learning process to determine LGF and SPM of a number so that the learning process can be more fun and not boring.

Research on the use of dakonmatika game media was done [4] in 2011. The results revealed that the dakonmatika game media can affect students' learning results. In addition, similar research has also been conducted [5] in 2015. The results revealed that the dakonmatika game effectively used in mathematics learning. Based on the background of the problem, it can be formulated problem of this research, that 
was "Is the use of dakonmatic game media can improve the mathematics learning results of the fourth grade students at elementary school 61 Parepare?"

\section{METHOD}

The approach used in this research was quantitative and qualitative approach (mixed methods) [6] research type used in this research was Classroom Action Research (CAR) [7] which aims to improve the quality of learning process and learning results in class. The subjects of this research were students of class IV SD Negeri 61 Parepare in the academic year $2017 / 2018$ of odd semester.

The procedures in this research were 4 (four) stages: (1) planning stage, (2) implementation stage, (3) observation and evaluation stage and (4) reflection stage. The CAR cycle can be seen in the picture below.

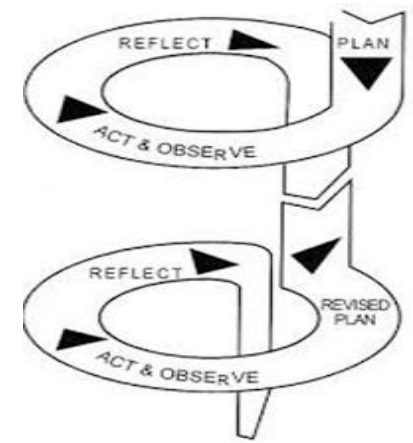

Fig.1. CAR Cycle Kemmis and Mc Taggart ([7])

Data of mathematics learning result of students obtained by giving test result of learning to the students at the end of meeting at cycle I and Cycle II. Students learning result data were analyzed descriptively consisting of mean, interval, median, standard deviation, minimum score and maximum score obtained by each student from the test given at the end of the cycle. Then to measure the level of mathematics learning results used categorization by 5 (five) scales based on the standard categories setby the Ministry of Education and Culture [8] as follows:

TABle I. CATEgORIZATION OF StUdEnTS' LEARNING RESUlt ABILITY

\begin{tabular}{cl}
\hline Level of Ability & Criteria \\
\hline $85-100$ & Very good \\
$65-84$ & Good \\
$55-64$ & Fair \\
$35-54$ & Low \\
\hline
\end{tabular}

\section{RESEARCH RESULT AND DISCUSSION}

\section{A. Data Analysis In Cycle I}

One of the students' activities demonstrating how to do the problem using dakonmatika media can be seen in Fig.2.

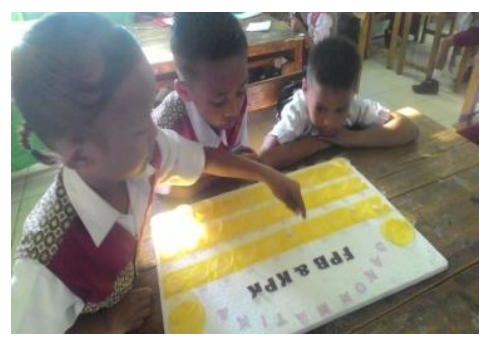

Students filled Dakon's hole to determine LGF of number 15 and 20

Fig. 2. Students Demonstrated How to Work the Test by Using Dakonmatika Media on Cycle I

At the end of the test, the students were given a test. The test result of students' mathematics learning in cycle I presented in essay form as much as 3 (three) questions. The test results of the students' were presented in Table 1

TABle II. Test Data of Students’ Mathematics LeARning RESUlts IN CYCLE I

\begin{tabular}{cc}
\hline Statistics & Statistics \\
\hline Subject & 22 \\
Ideal score & 100 \\
High Scores & 88,23 \\
Lowest Score & 47,05 \\
Range Score & 41,18 \\
Average & 71,06 \\
Standard Deviation & 9,88 \\
Median & 70,58 \\
\hline
\end{tabular}

The data in Table II showed that after using the dakonmatika media, the average learning achievement test of students of 71.06 indicated that the students' learning results were in the high category.

Furthermore, if the results of the students' learning tests were grouped into 5 (five) categories, then the distribution and percentage obtained as in Table III.

TABle. III. Frequency and Percentage Distribution of Students' MATHEMATICS LEARNING RESULTS CYCLE I

\begin{tabular}{|c|c|c|c|}
\hline $\begin{array}{c}\text { Scores } \\
\text { Interval }\end{array}$ & Category & Frequency & $\begin{array}{c}\text { Percentage } \\
(\%)\end{array}$ \\
\hline $85-100$ & Very high & 2 & 9 \\
\hline $65-84$ & High & 17 & 77 \\
\hline $55-64$ & Fair & 3 & 14 \\
\hline $35-54$ & Low & 0 & 0 \\
\hline $0-34$ & Very low & 0 & 0 \\
\hline \multicolumn{2}{|c|}{ Total } & 22 & 100 \\
\hline
\end{tabular}

Based on the data in Table 2 showed that the frequency and percentage of mathematics learning results of students using dakonmatika media in cycle I found that 2 (two) students or $9 \%$ were in very high category, 17 (seventeen) students or $77 \%$ were in high category and 3 (three) students or $14 \%$ were in fair category.

\section{B. Data Analysis in Cycle II}

Test results of students in cycle II presented in essay form as much as 2 (two) questions. The results of students' 
mathematics learning have increased. The test results of students in cycle II are presented in Table IV.

Table IV. The Data Test of Students' Mathematics Learning in CYCLE II

\begin{tabular}{cc}
\hline Statistic & Statistic Score \\
\hline Subject & 22 \\
Ideal Score & 100 \\
High Scores & 100 \\
Lowest Score & 62,50 \\
Range Score & 37,50 \\
Average & 82,73 \\
Standard Deviation & 10,17 \\
Median & 81,25 \\
\hline
\end{tabular}

The data in table 3 showed that after using dakonmatika media, obtained the average of students' learning achievement test that was 82,73 indicated that the result of students' mathematics learning was in high category. Furthermore, if the results of the students' mathematics learning result was grouped into 5 (five) categories, it would get the distribution and the percentage as in Table 4.

Table V. Distribution and Percentage Frequency of Students' MATHEMATICS LEARNING RESULTS IN CYCLE II

\begin{tabular}{cccc}
\hline $\begin{array}{c}\text { Interval } \\
\text { Score }\end{array}$ & ategory & Frequency & Precentage (\%) \\
\hline $85-100$ & Very high & 10 & 45 \\
$65-84$ & High & 11 & 50 \\
$55-64$ & Fair & 1 & 5 \\
$35-54$ & Low & 0 & 0 \\
$0-34$ & Very low & 0 & 0 \\
\hline \multicolumn{7}{r}{ Total } & 22 & 100 \\
\hline
\end{tabular}

The data in table V. showed that the frequency and percentage of mathematics learning results of the students using dakonmatika media in cycle II found that there were 10 (ten) students or $45 \%$ were in very high category, 11 (eleven) students or $50 \%$ were in high category and 1 (one) student or $5 \%$ were in enough category.

Based on the results of analysis of cycles I and II, it could be categorized that there was an increase of the mathematics learning result by using dakonmatika media of the fourth grade students at elementary school 61 Parepare, this could be seen in Diagram 2.

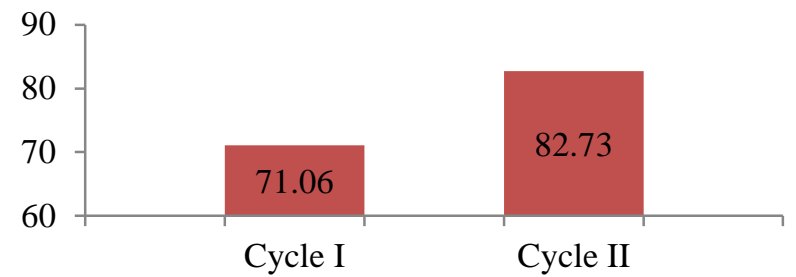

Fig. 3. Average Comparison of Students' Matematics Learning Results from Cycle I to Cycle II

Based on Diagram 2 showed that the average score of mathematics learning results of students has increased in the first cycle of 71.06 to 82.73 in cycle II.

\section{REFERENCES}

[1] Heruman. Mathematics Learning Model inElementary School. Bandung: PT. Youth Rosdakarya. 2008.

[2] Husna, A. 100+ Traditional Games. Yogyakarta: CV Andi Offset. 2009.

[3] Abdullah, Sanep. Dakon as a Mathematical Learning Tool. 2015 (Online),

(http://www.academia.edu/6756654/dakon_seba_the_the_mathemati cal apparatus), accessed on April 22, 2017.

[4] Ahmad Sobari. The Effect of Using Dakon Educational Equipment On Student Math Learning Results. 2011. (Online), (http://repository.uinjkt.ac.id/dspace/bistream/123456789/3043/1/ah mad\%20sobari-fitk.pdf), accessed on April 16, 2017

[5] Evi Febriana. Contribution of Dakon Board Usage in Mathematics Learning of Multiplication Materials to Student's Achievement in Class II MIM 02 Merden Banjarnegara. 2015. (Online), (http://digilib.uin-suka.ac.id/16500/2/11480004_bab-i_iv-atauv_daftar-pustaka.pdf), accessed on April 16, 2017.

[6] Creswell, John W. Research Design A Qualitative, Quantitative, and Mixed Approach. Yogyakarta: Pustaka Belajar. 2012.

[7] Suharsimi Arikunto, Suhardjono and Supardi. Classroom Action Research. Jakarta: PT Bumi Aksara. 2008.

[8] Buhaerah. Development of Problem Based Learning Tools on Class IX Materials of SMP Makassar. Thesis not published. Makassar: UNM Graduate Program. 2009.

[5] Evi Febriana. Contribution of Dakon Board Usage in Mathematics Learning of Multiplication Materials to Student's Achievement in Class II MIM 02 Merden Banjarnegara. 2015. (Online), (http://digilib.uin-suka.ac.id/16500/2/11480004_bab-i_iv-atauv_daftar-pustaka.pdf), accessed on April 16, 2017. 